Proc. Estonian Acad. Sci. Biol. Ecol., 2004, 53, 4, 306-316

\title{
Re-allocation of the Baltic herring fishing possibilities
}

\author{
Robert Aps ${ }^{\mathrm{a}^{*}}$, Hans Lassen $^{\mathrm{b}}$, Jake C. Rice $^{\mathrm{c}}$, \\ Ksenia Andrejeva ${ }^{\mathrm{d}}$, and Jaan $\mathrm{Aps}^{\mathrm{e}}$ \\ ${ }^{\text {a }}$ Estonian Marine Institute, University of Tartu, Mäealuse 10a, 12618 Tallinn, Estonia \\ b International Council for the Exploration of the Sea, H. C. Andersens Boulevard 44-46 DK 1553, \\ Copenhagen V, Denmark; hans@ices.dk \\ ${ }^{c}$ DFO - Canada Science Advisory Secretariat, Department of Fisheries and Oceans, 200 Kent \\ Street, Ottawa, Ontario, Canada K1A 0E6; ricej@dfo-mpo.gc.ca \\ d Estonian Marine Institute, University of Tartu, Mäealuse 10a, 12618 Tallinn, Estonia; \\ ksenia.andrejeva@ut.ee \\ e Faculty of Economics and Business Administration, University of Tartu, Narva 4, 51009 Tartu, \\ Estonia; jaan.aps@ekm.envir.ee
}

Received 17 March 2004, in revised form 19 August 2004

\begin{abstract}
Re-allocation of the Baltic herring fishing possibilities is based on biological information on the fish stock identity. Any revised allocation scheme must secure that each country maintains as close as possible its Total Allowable Catch (TAC) share it would be entitled to under the existing allocation scheme irrespective of the area split and independently of how the TAC might be composed. Possible theoretical solutions to the problem of fishery resource re-allocation are exemplified by an analysis of the proposed split of the management areas for the herring resources in the Baltic Sea. As a basic principle it is proposed that any quota re-allocation related mismatch of fishing interests be solved through quota swaps and buying/selling of quotas among the countries. A quota swap may involve different species, for example swapping quotas of cod for quotas of herring. This requires that a price per quota unit be established for the individual species perhaps on a stock level.
\end{abstract}

Key words: Baltic herring, shared fishery resources, value based fishing quota allocation, fishing quota swaps.

\section{INTRODUCTION}

Up to 2004 the International Baltic Sea Fisheries Commission (IBSFC) managed the Baltic herring in three management units: (1) Gulf of Bothnia (Subdivision 31), (2) Bothnian Sea (subdivisions $30+29 \mathrm{~N}$ ), and (3) Western and Central Baltic (subdivisions 22-29S + 32). Subdivisions in the Baltic Sea are shown in Fig. 1.

*Corresponding author, robert.aps@ut.ee 


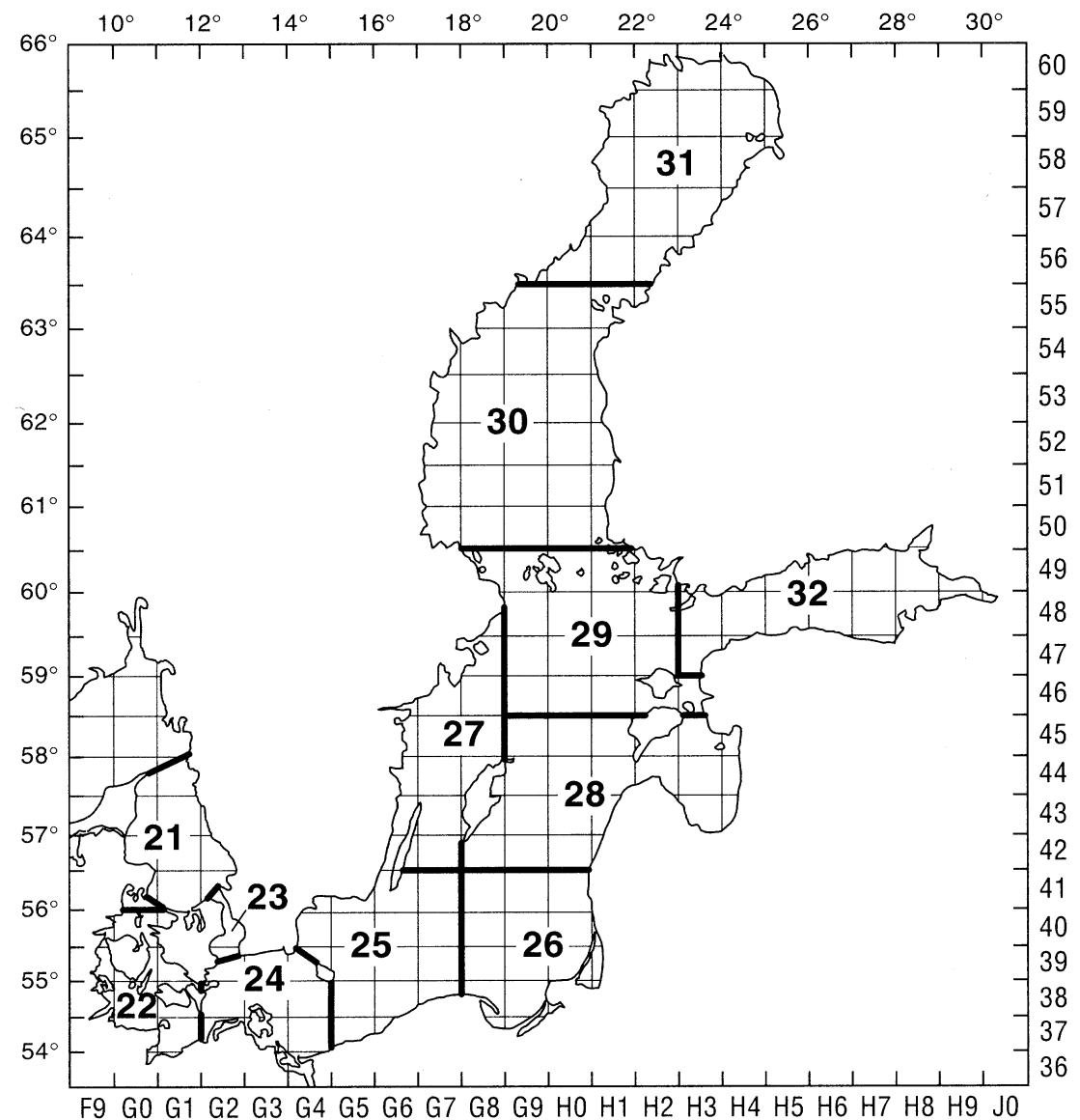

Fig. 1. Baltic Sea ICES subdivisions in IBSFC Convention Area for fisheries assessment and fisheries statistics purposes (www.ices.dk).

Vertebrae counts, parasite markers (Anisakis simplex), tagging data, and different microstructure of otoliths have demonstrated that the Western and Central Baltic herring are not a single stock (Anon., 2002; Kornilovs, 2004). The scientific discussion on how best to assess the herring resources in the Baltic has been heated and many approaches have been taken over the years. Difficulties encountered in the identification of the Baltic herring stock structure using meristic and morphological characters, otolith morphology and microstructure, tagging results, parasite markers, and the results of genetic studies are presented and discussed in more detail in Anon. (2002), Kornilovs (2004), and Sjöstrand (1989).

This mismatch between the stock structure and management units has created real difficulties for the rational use and conservation of the Baltic herring fishery resources (Ojaveer, 2002; Aps, 2004; Kornilovs, 2004; Ojaveer et al., 2004). For example, two components of the combined Baltic herring stock (Central Baltic 
herring in subdivisions 22-29S + 32 and the Gulf of Riga herring) show distinct divergent biomass trends; currently stock biomass of the Central Baltic herring is historically low, whereas the herring stock in the Gulf of Riga is at a historical high.

In 1997 the IBSFC established a Strategy Working Group to draft long-term objectives and strategies for managing Baltic herring. It was agreed that the strategy should be based on the most recent scientific advice as available from the International Council for the Exploration of the Sea (ICES). This group proposed in 2003 a new scheme for the management of the Western and Central Baltic herring with three management units: Western Baltic (subdivisions 22-24), Central Baltic (subdivisions 25-29S + 32, excl. the Gulf of Riga), and the Gulf of Riga. It was further proposed that, if such a revised management system was implemented, allocations should reflect historical fishing patterns and be based on the data used by the ICES. It was also proposed that future allocations should reflect recent allocations as closely as possible. However, any revised allocation agreed among the countries would include in an individual year winner and loser countries compared to the existing allocation scheme (Aps, 2004).

It should be stressed that the ratio of annual national allocations agreed by the IBSFC are made without prejudice and cannot be taken as reflecting any general concept, and it may not be used for fishery resource allocation in the future. However, in practice relative stability over time has been an important instrument for the IBSFC in seeking a solution in sharing common fishery resources (Aps, 2004).

Today, the IBSFC is facing the difficult challenge to adjust its Baltic herring stock management units to the structure of herring populations. In practical terms this means re-allocation of the Baltic herring fishery resources amongst the IBSFC Contracting Parties. Estonia, Latvia, Lithuania, and Poland became members of the European Union on 1 May 2004. Therefore, the problem of the re-allocation of the Baltic herring fishing quota may move to a different political forum but its substance remains.

This paper investigates possible theoretical solutions to the problem of fishery resource re-allocation and exemplifies the issue by an analysis of the proposed split of the management areas for the herring resources in the Baltic Sea.

\section{RESULTS AND DISCUSSION}

\section{List of symbols}

TAC - Total allowable quota.

$\bar{k}$ - Allocation keys (fraction of total TAC) among the countries; $\bar{k}$ is a matrix $\left(n_{c} \times 1\right)$, countries $=1,2, \ldots, n_{c} . \quad \bar{k}^{T}=\left\{k_{1}, k_{2}, \ldots, k_{n_{c}}\right\}$ with $0 \leq k_{i} \leq 1$ for every $i$ and $\sum_{c \in c o u n t r y} k_{c}=1$. 
$t a c_{c}$ - The allocated quota to country $c \overline{\operatorname{tac}}^{T}=\left\{\operatorname{tac}_{1}, \operatorname{tac}_{2}, \ldots, \operatorname{tac}_{n_{c}}\right\}$.

$t_{a}$ - Quota for area $a, a=1, \ldots, n_{a}$ with $t^{-T}=\left\{t_{1}, t_{2}, \ldots, t_{n_{a}}\right\}$.

$\underline{n}=\left\{n_{c, a}\right\} \quad c=1, \ldots, n_{c}$ and $a=1, \ldots, n_{a}-$ Allocation to each country from each quota area $0 \leq n_{c, a} \leq 1$ for $\forall c, a$ and with $\sum_{c \in c o u n t r y} n_{c, a}=1$ for each $a$.

$\bar{\varepsilon}^{T}=\left\{\varepsilon_{1}, \varepsilon_{2}, \ldots, \varepsilon_{n_{c}}\right\}-$ Difference between the total allocations to a country under the old and the new scheme.

$E[\bar{\varepsilon}]$ - Average value of $\bar{\varepsilon}$.

$\lambda$ - Upper limit on the absolute difference between the quota to any country under the old and the new allocation scheme.

\section{Theory}

The area is already under management based on a Total Allowable Catch (TAC) system with fixed relative sharing among participant countries in the fishery. This is the model used in the EU Common Fisheries Policy where the agreed sharing key is the so-called relative stability. The biological reasons for advocating separate area TACs are that the developments in the stocks and hence of the fishing possibilities in the areas are not in synchrony. There will be periods when there are good prospects in one area while prospects are poor in other areas, and this will be reversed over time.

Let TAC be the total quota and $\bar{k}$ be the existing allocation keys (fraction of total TAC) among the countries; $\bar{k}$ is a matrix $\left(n_{c} \times 1\right)$, countries $=1,2, \ldots, n_{c}$. $\bar{k}^{T}=\left\{k_{1}, k_{2}, \ldots, k_{n_{c}}\right\}$ with $0 \leq k_{i} \leq 1$ for every $i$ and $\sum_{c \in c o u n t r y} k_{c}=1$.

The allocated quota $t a c_{c}$ to country $c$ is then $t a c_{c}=k_{c} * \mathrm{TAC}, c=1,2, \ldots, n_{c}$, or in matrix notation $\overline{t a c}=\mathrm{TAC} * \bar{k}$, with $\sum_{c \in c o u n t r y} t_{c}=\mathrm{TAC}$, because $\sum_{c \in c o u n t r y} k_{c}=1$.

The management scheme is changed so that in the future individual area quotas $t_{a}$ are set for each area $a=1, \ldots, n_{a}$.

Defining new allocation keys can be formulated mathematically. Let the column vector $t^{-T}=\left\{t_{1}, t_{2}, \ldots, t_{n_{a}}\right\}$ be the individual TACs by area and the overall $\mathrm{TAC}=\sum_{a \in a r e a} t_{a}$. The allocation to each country from each quota area is defined by a matrix $\underline{\underline{n}}=\left\{n_{c, a}\right\} \quad c=1, \ldots, n_{c}$ and $a=1, \ldots, n_{a}$ with $0 \leq n_{c, a} \leq 1$ for $\forall c, a$ and with $\sum_{c \in c o u n t r y} n_{c, a}=1$ for each $a$. 


\section{Allocation equity}

The new allocation shall conform to some form of equity compared with the old allocation. Each country will want to maintain its old allocation in terms of fishing possibilities, that is

$$
\mathrm{TAC} * \bar{k}=\underline{\underline{n}} * \bar{t}
$$

with

$$
\mathrm{TAC}=\sum_{a \in \text { area }} t_{a}
$$

It is therefore of interest to study the possible solutions to

$$
\mathrm{TAC} * \bar{k}=\underline{\underline{n}} * \bar{t}+\bar{\varepsilon}
$$

for different conditions imposed on $\bar{\varepsilon}$. For this analysis to be realistic it must include restrictions on $\underline{\underline{n}}$ that follow from restrictions on access by different countries to different geographical fishing areas.

Here we shall investigate three different conditions. These are defined below.

Strong equity $\bar{\varepsilon}=\overline{0}$

With unrestricted access for all players to all areas there is only one solution to this problem that is general for all possible area quotas: $n=\{\bar{k}, \bar{k}, \ldots, \bar{k}\}, j=1, \ldots, a$ as can be seen by considering the situation where there is only a positive quota in a single area and quotas in all other areas are zero. For a specific set of quotas $\bar{t}$ there are infinitely many solutions $\underline{\underline{n}}$.

Mean equity $E[\bar{\varepsilon}]=\overline{0}$

The solution is

$$
\begin{aligned}
\mathrm{TAC} * \bar{k} & =\underline{\underline{n}} * E[\bar{t}] \\
\text { with TAC } & =\sum_{a \in \text { area }} t_{a} .
\end{aligned}
$$

This equation has infinitely many solutions for $\underline{\underline{n}}$.

Upper bound equity

$$
\operatorname{Max}\left[\left|\varepsilon_{c}\right|\right]<\lambda
$$

or in relative terms

$$
\left|\varepsilon_{c}\right|<\lambda * t a c_{c} \text { for } \forall c \in \text { country. }
$$


In this case the deviation between the allocation to each country under the old and the new allocation scheme is kept within certain bounds. There is a lower bound on $\lambda$ below which there is no solution whatsoever. There is no simple solution, for a choice of $\lambda$ there will be either infinitely many solutions or none at all.

\section{Differences between strong and other equity forms}

In investigating the mean or the upper boundary equity and deviation from strong equity the mean is taken over the observed set of catches by area (depends on the species and stock). These catches are assumed to represent possible combinations of area TACs to be experienced in the future. This simulation approach is based on the practice that past catch performance is often a dominating concern when agreeing allocation keys among countries.

\section{Access restrictions}

In practice, defining a new allocation scheme is more complicated because there are additional bounds on how the new allocation scheme $\underline{n}$ can be chosen. Access to the herring in the Gulf of Riga may serve as an example. Only Estonia and Latvia will have access to this area under the revised scheme while under the old scheme all countries had a share in the quota of which the herring in the Gulf of Riga was part. However, under the old allocation scheme fishing access to the Gulf of Riga was also limited to Estonia and Latvia.

If we impose restrictions on $n$, solutions that exist to the equity problem may disappear and there could be no solutions at all under strong and mean equity. Constraints that can be imposed on $n$ will be in the form that certain columns in $n$ are partly predefined, i.e. that certain countries have preference to the exploitation of resources in certain areas while other countries do not have access. As it is at least theoretically possible that the entire TAC would consist of a contribution from a single area to which not all players have access it is clear that strong equity cannot generally be met when respecting access restrictions.

If a scheme with strong equity is introduced then this must be associated with a trading scheme allowing those countries that have fishing rights but no access to the area to trade these rights with countries that have free fishing capacity and access to the areas. An interesting question is: what is the value of a quota without access rights? The negotiating problem can be defined as a simple sellerbuyer situation, while more complicated schemes (e.g. triangle trading) are not included. Table 1 summarizes the negotiating positions.

According to Munro et al. (2004) the precise allocation criteria (allocation rules) would always be a matter of negotiation among the countries sharing common fisheries resources, and the general sharing (equity) principles are considered to be useful in framing the expectations of the bargaining parties. At the same time such allocation formulae should reflect the agreed political, social, and economic objectives (Butterworth et al., 2004). 
Table 1. Negotiating positions for sellers and buyers of fishing rights. The analysis assumes that the seller who has access right also has fishing capacity available

\begin{tabular}{ll|c|c|c}
\hline \multirow{2}{*}{\multicolumn{2}{c|}{ Value to seller }} & \multicolumn{3}{|c}{ Value to buyer } \\
\cline { 3 - 5 } & $\begin{array}{c}\text { With access rights } \\
\text { with surplus } \\
\text { fishing capacity }\end{array}$ & $\begin{array}{c}\text { With access rights } \\
\text { without surplus } \\
\text { fishing capacity }\end{array}$ & $\begin{array}{c}\text { Without } \\
\text { access } \\
\text { right }\end{array}$ \\
\cline { 3 - 5 } & Full market value & Nil & Nil \\
\hline With access rights & $\begin{array}{l}\text { Full Market } \\
\text { value }\end{array}$ & Full market prices & No deal & No deal \\
Without access rights & Nil & Reduced market price & No deal & No deal
\end{tabular}

\section{Revised allocation scheme}

For any revised allocation scheme to be acceptable to all IBSFC Contracting Parties fishing for the Baltic herring, the scheme must secure that each country maintains the TAC share it would be entitled to under the existing allocation scheme irrespective of the area split and independently of how the TACs might be composed. Each IBSFC Contracting Party will want to maintain its old allocation in terms of fishing possibilities.

The revised IBSFC scheme for herring is to split the existing herring quota into three TAC units: subdivisions 22-24, subdivisions 25-29S and 32, and the Gulf of Riga (Fig. 1). Based on historical rights Denmark, Germany, Poland, and Sweden would have TAC rights in subdivisions 22-24, all countries in the open parts of subdivisions 25-29S and 32, while only Estonia and Latvia would have TAC rights in the Gulf of Riga.

IBSFC also manages herring in Subdivision 30 (Bothnian Sea) and in Subdivision 31 (Gulf of Bothnia). Management of these herring stocks is not affected by the changes and hence not included in the following considerations.

The revised allocation of the Baltic herring fishery resources shall conform to some form of equity compared with the old allocation. If strong equity should be implemented then this means that for example Estonia would have a herring quota in the Western Baltic (subdivisions 22-24). It would also mean that other Contracting Parties to IBSFC would have a herring quota in the Gulf of Riga. It may be of little interest to Estonia to have such a herring quota in the Western Baltic if Estonia has no fleet to fish this quota. Other Contracting Parties to IBSFC, on the contrary, may not be interested in a herring quota in the Gulf of Riga as they would have no fleet that has experience in this fishing; moreover, Latvia and Estonia might not be interested in allowing other countries fishing rights in the Gulf of Riga.

It might be possible to construct a scheme that would after fixing the allocation scheme for example in the Western Baltic and in the Gulf of Riga adjust the allocation in residual areas. For herring such a residual area would be the Central Baltic (subdivisions 25-29S and 32, excluding the Gulf of Riga). The reason why 
this area would be chosen as the residual area is that all players have access to this area and have historical fishing rights in this area. However, this scheme though mathematically feasible will not be transparent and might lead to undesirable allocations. Furthermore, there are TAC situations (e.g. the 2003 situation) when the solution implies a negative allocation to some country, that is within the fixed areas (the Western Baltic and the Gulf of Riga) the allocation would be more than some IBSFC members with access to these areas would be entitled to. This means that even under this fairly complicated scheme there is a need for quota swaps with one country offering one species and another offering a different species.

If the new allocation scheme on the Baltic herring is agreed with individual allocations for each of the new management units then there will be winner and loser countries. However, which countries will be among the winners and which among the losers will depend on the ratio between the TACs agreed for the individual new management units. Possible consequences of the implementation of the revised Baltic herring allocation scheme are illustrated with an example below. This example is only illustrative and has no bearing on how an actual scheme might be constructed.

Calculations are based on the Baltic herring catch statistics used by the ICES Baltic Fisheries Assessment Working Group (Anon., 2004a) and compiled by IBSFC management units as follows:

1. Western Baltic, subdivisions 22-24 (1974-2001),

2. Central Baltic, subdivisions 25-29S + 32 (1974-2001),

3. Gulf of Riga (1970-2001).

The Baltic herring TAC (Anon., 2003) and the landed catch value per tonne by the IBSFC management areas as given in Table 2 were used in the re-allocation example calculations. The landed herring catch value used was taken on a general level of the EC herring guide price for 2004 with downward correction for landings from subdivisions 25-29S + 32 (Anon., 2004b).

The analysis could be expanded by considering the individual sharing within the consolidated group of EC member states (Denmark, Finland, Germany, and Sweden). However, this sharing includes additional complications involving arrangements related to the European Economic Areas agreement and the Finnish and Swedish EU accession treaties.

Table 2. Baltic herring quotas in tonnes (Anon., 2003) and the catch values in euros per tonne (Anon., 2004b, modified) by IBSFC management areas

\begin{tabular}{l|c|c}
\hline $\begin{array}{c}\text { IBSFC } \\
\text { Management Area }\end{array}$ & $\begin{array}{c}\text { TAC, } \\
\text { tonne }\end{array}$ & $\begin{array}{c}\text { Value, } \\
\text { euro per tonne }\end{array}$ \\
\hline $22-29 S+32$ & 143000 & 216.08 \\
$22-24$ & 46000 & 250 \\
$25-29 S+32$ & 62000 & 200 \\
Gulf of Riga & 35000 & 200
\end{tabular}


The relative allocation in the Central Baltic (subdivisions 25-29S + 32) was calculated based on fixing the herring allocation in the Western Baltic (subdivisions 22-24) and in the Gulf of Riga. This would lead to the allocation sheme presented in Table 3.

The percentage allocation of the herring in the Central Baltic would imply that Latvia would need to pay back $17.88 \%$ of the herring TAC for subdivisions $25-29 \mathrm{~S}$ and 32 (excluding the Gulf of Riga). This is obviously not possible and is suggesting that Latvia would need to pay its partners in some other currency, e.g. cod.

Table 4 shows the same allocation in tonnes. Here the Contracting Parties with a negative allocation get a TAC of zero tonnes (area by area). As the sum of positive allocations is more than 100 , the allocations are adjusted to a sum 100 by down grading all with the same proportion. The difference is the new allocation minus the old allocation.

Table 5 shows the allocations in euros, which are based on the allocations from Table 3. The prices are weighted by the area TACs, and prices per tonne are

Table 3. Allocation (\%) of the Baltic herring TAC by IBSFC Contracting Parties and by Management Areas

\begin{tabular}{l|c|r|r|r}
\hline & IBSFC current & \multicolumn{3}{|c}{ Suggested allocation per areas } \\
\cline { 3 - 5 } & allocation key & $22-24$ & $25-29 \mathrm{~S}+32$ & Gulf of Riga \\
\hline Estonia & 10.14 & 0.00 & 0.64 & 40.30 \\
Denmark, Finland, & 54.95 & 88.51 & 61.07 & 0.00 \\
$\quad$ Germany, Sweden & & & & \\
Latvia & 6.86 & 0.00 & -17.88 & 59.70 \\
Lithuania & 2.14 & 0.00 & 4.94 & 0.00 \\
Poland & 20.14 & 11.49 & 37.93 & 0.00 \\
Russia & 5.77 & 0.00 & 13.31 & 0.00
\end{tabular}

Table 4. Allocation ( $\mathrm{t}$ ) of the Baltic herring TAC by IBSFC Contracting Party and by the Management Areas

\begin{tabular}{l|c|c|c|c|c}
\hline & $\begin{array}{c}\text { IBSFC } \\
\text { allocation }\end{array}$ & $\begin{array}{c}\text { Difference, } \\
\mathrm{t}\end{array}$ & $22-24$ & $25-29 \mathrm{~S}+32$ & Gulf of Riga \\
\hline TAC, $\mathrm{t}$ & 143000 & & 46000 & 62000 & 35000 \\
\hline Estonia & 14500 & -60 & 0 & 335 & 14105 \\
Denmark, Finland, & 78579 & -5743 & 40715 & 32121 & 0 \\
$\quad$ Germany, Sweden & & & & & \\
Latvia & 9810 & 11085 & 0 & 0 & 20895 \\
Lithuania & 3060 & -464 & 0 & 2596 & 0 \\
Poland & 28800 & -3567 & 5285 & 19948 & 0 \\
Russia & 8251 & -1251 & 0 & 7000 & 0
\end{tabular}


Table 5. Allocation (value in euros) of the Baltic herring TAC by IBSFC Contracting Parties and by management units

\begin{tabular}{l|c|c|c|c|c}
\hline & $\begin{array}{c}\text { IBSFC allocation, } \\
\text { euro }\end{array}$ & $\begin{array}{c}\text { Difference, } \\
\text { euro }\end{array}$ & $22-24$ & $25-29 \mathrm{~S}+32$ & Gulf of Riga \\
\hline TAC value & 30900000 & \multicolumn{1}{c}{11500000} & 12400000 & 7000000 \\
\hline Estonia & 3133260 & -245208 & 0 & 67052 & 2821000 \\
$\begin{array}{l}\text { Denmark, Finland, } \\
\quad \text { Germany, Sweden }\end{array}$ & 16979550 & -376722 & 10178650 & 6424178 & 0 \\
$\quad$ Latvia & 2119740 & 2059260 & 0 & 0 & 4179000 \\
Lithuania & 661260 & -142051 & 0 & 519209 & 0 \\
Poland & 6223260 & -912272 & 1321350 & 3989638 & 0 \\
Russia & 1782930 & -383007 & 0 & 1399923 & 0
\end{tabular}

different in each area. The difference is the new allocation minus the old allocation. Note that the TAC difference can be 0 while the value in euros is different from 0 . In this example, made for illustrative purposes only, Latvia would gain about EUR 2059 260, while all other Contracting Parties would be among the losers.

As a basic principle it is proposed that this mismatch of allocation and fishing interests be solved through quota swaps and the buying or selling of quotas among the countries. A quota swap may involve different species, i.e. swapping quotas of cod for quotas of herring. This requires that a price per quota unit be established for the individual species. Pay back shall be distributed among the other Contracting Parties or perhaps to only one Party.

\section{CONCLUSIONS}

For practical reasons only two possible solutions could be considered: (1) strong equity without regard for access and combined with trading or swapping of quota rights or (2) an allocation scheme based on upper bound equity either defined as an absolute upper bound or a relative upper bound. Introduction of a scheme with strong equity must be associated with a trading scheme allowing those countries that have fishing rights but no access to the area to trade these rights with countries that have free fishing capacity and access to the areas.

\section{REFERENCES}

Anon. 2002. Report of the Study Group on Herring Assessment Units in the Baltic Sea. ICES CM 2002/H:04.

Anon. 2003. International Baltic Sea Fishery Commission. Proceedings of the Twenty Ninth Session. Vilnius, Lithuania 29 September-3 October 2003.

Anon. 2004a. Report of the Baltic Fisheries Assessment Working Group 13-22 April 2004. ICES, Copenhagen. Advisory Committee on Fishery Management, ICES CM 2004/ACFM:22. 
Anon. 2004b. Council Regulation (EC) No 2326/2003 of 19 December 2003. Official J. EU. L345, p. 28.

Aps, R. 2004. Management of shared Baltic fishery resources. In Management of Shared Fish Stocks (Payne, A. I. L., O’Brien, C. M. \& Rogers, S. I., eds.), pp. 190-201. Blackwell, Oxford.

Butterworth, D. S., Cochrane, K. L., Dunn, M. R. \& Fox, C. J. 2004. International approaches to management of shared stocks: fisheries, management and external driver issues. In Management of Shared Fish Stocks (Payne, A. I. L., O’Brien, C. M. \& Rogers, S. I., eds.), pp. 348-355. Blackwell, Oxford.

Kornilovs, G. 2004. Problems of herring assessment and management in the Baltic Sea. In Management of Shared Fish Stocks (Payne, A. I. L., O’Brien, C. M. \& Rogers, S. I., eds.), pp. 42-55. Blackwell, Oxford.

Munro, G., Willmann, R. \& Cochrane, K. L. 2004. On the management of shared fish stocks: critical issues and international initiatives to address them. In Management of Shared Fish Stocks (Payne, A. I. L., O’Brien, C. M. \& Rogers, S. I., eds.), pp. 95-112. Blackwell, Oxford.

Ojaveer, E. 2002. The role of ICES in the assessment and management of resources in the Baltic Sea. ICES Marine Science Symposia, 215, 582-589.

Ojaveer, E., Raid, T. \& Suursaar, Ü. 2004. On the assessment and management of local herring stocks in the Baltic Sea. In Management of Shared Fish Stocks (Payne, A. I. L., O’Brien, C. M. \& Rogers, S. I., eds.), pp. 240-250. Blackwell, Oxford.

Sjöstrand, B. 1989. Assessment review: exploited pelagic stocks in the Baltic. Rapp. P-V Réun. Cons. Int. Explor. Mer, 190, 235-252.

\title{
Läänemere räime püügivõimaluste ümberjaotamine
}

\author{
Robert Aps, Hans Lassen, Jake C. Rice, \\ Ksenia Andrejeva ja Jaan Aps
}

Läänemere räime püügivõimaluste ümberjaotamise vajadus on tingitud uuest bioloogiainfost, mis on ilmnenud selle kala looduslike ühikute kohta. Samal ajal peab uus püügivõimaluste jaotus kindlustama igale riigile tema endise osaku Läänemere räime üldkvoodist ja seda sõltumata mereala jaotusest ja üldkvoodi suurusest. Läänemere räime püügivõimaluste ümberjaotamisel tekkivate võimalike mittevastavuste korral seisneb üks põhimõttelisi lahendusi selle kala kvoodiosakute vahetamises, ostmises ja müügis. Kvoodivahetused võivad hõlmata nii erinevaid kui ka samu kalaliike. Tursakvoote saab vahetada näiteks rahaliselt väärtuselt proportsionaalsete räimekvootide vastu. Selline vahetus eeldab aga eelnevaid kokkuleppeid erinevate kalaliikide kvoodiühikute hindade osas. 